\title{
Problems of land legal relations in the agro- industrial complex
}

\author{
Anna Ozernaya ${ }^{1 *}$ \\ ${ }^{1}$ Institute of Service Sector and Entrepreneurship (branch) of Don Technical University in the city of \\ Shakhty, Shevchenko lane, 147, Shakhty, 346500, Russia
}

\begin{abstract}
This article is devoted to the analysis of the problems of land legal relations in the agro-industrial complex. The author studied the theoretical aspects of the regulation of land legal relations in the agroindustrial complex, the main problems in this area, and also developed and proposed ways to solve the problems indicated in the article.
\end{abstract}

\section{Introduction}

This work is devoted to a very urgent problem of today - the problem of the development of land legal relations in the agro-industrial complex of Russia.

Today, land law is one of the main branches of law governing relations in the field of property rights to land, the use of land, including agricultural land.

Thus, we can conclude that the development of solutions to problems related to land legal relations in the field of the agro-industrial complex is one of the most relevant in the field of land law. To solve the identified problems that affect the interests of both the citizen and the state as a whole, it is necessary to apply a scientifically based concept that takes into account the socio-economic situation in the country.

Based on the above, we consider it necessary to find effective mechanisms that will help in regulating the turnover of agricultural land plots, conduct a comprehensive analysis of legislation and identify gaps and conflicts in this area of legal regulation.

\section{Methods}

This research was carried out using the following methods: comparative legal, historical legal, formal legal methods, as well as the method of systemic and multivariate analysis.

\section{Research results}

For the rational use of agricultural land, the author has developed the following recommendations:

\footnotetext{
* Corresponding author: Polidi1995@yandex.ru
} 
- to complete the development and formation of a system of land tenure and land use, allowing citizens who are engaged in agriculture to preserve their land. Here, it is necessary to ensure the protection of the rights of every citizen in the issue of land use, that is, to regulate the acquisition and use of land plots for growing crops;

- to form a land market that meets all the requirements and its infrastructure;

- to create conditions and incentives, possibly incentives for people to competently and effectively use land, and for products to meet the requirements of each buyer;

- to ensure the protection of land ownership so that the land that is issued by the state is used for its intended purpose and does not stand idle. You also need to create a state body that could be engaged in the protection and monitoring of the correct use of land.

We propose to clarify the concept of a land share in the Federal Law of July 24, 2002 No. 101-FZ «On the turnover of agricultural land». We also propose in the same Federal Law to expand the list of cases when land plots from agricultural land, which are in state or municipal ownership, can be provided without bidding.

\section{Theoretical aspects of regulation of land legal relations in the agro-industrial complex}

Rational use of land resources is closely related to land legal relations. This factor is one of the main in the development of the agro-industrial complex.

Today, there are transformations in the agricultural supply system, as well as the formation of a new agricultural policy at various levels. This is due, first of all, to a multitude of market transformations of various levels in the territory of the Russian Federation. Land relations as one of the constituent aspects of agricultural policy is the most important factor in the development and stabilization of the agro-industrial complex in Russia. These changes can also have a positive effect on the growth of the welfare of the population of the state. [1].

Agriculture today is one of the priority national projects, since the agricultural complex has a number of serious problems that require timely responses and solutions, and also requires the search for new solutions in the formation of agriculture in order to establish tactics for influencing various economic processes. The most urgent problem in this area, in our opinion, is the problem of the development of land legal relations in the agro-industrial complex.

Agricultural lands include lands that are outside of settlements [2]. These lands are provided for the development of agriculture. This category of land needs special protection, since there is a danger of encroachment on their area, the development of negative factors to reduce the level of fertility, etc.

The objects of land legal relations in agriculture include:

- agricultural grounds;

- lands occupied by on-farm roads, communications, ameliorative protective forest plantations, water bodies (including ponds formed by water retaining structures on watercourses and used for the purposes of pond aquaculture), as well as buildings, structures used for production, storage and primary processing agricultural products.

Agricultural lands have a certain status and for the effective use of these lands it is necessary to solve a number of the following tasks:

- to preserve and rationally use farmland;

- to ensure the level of soil fertility in connection with the growing production of ecologically high-quality agricultural products;

- adhere to the requirements for environmental protection.

Note that the state policy aimed at regulating the rational use of agricultural lands is based on the following programs: 
- fundamentals of the state policy of using the land fund of the Russian Federation for 2012 - 2020;

- the doctrine of food security of the Russian Federation;

- the concept of sustainable development of rural areas of the Russian Federation for the period up to 2020;

- strategy for sustainable development of rural areas of the Russian Federation for the period up to 2030 ;

- a concept for the development of state monitoring of agricultural land and land used or provided for agriculture.

However, this range of government programs and strategies is not exhaustive and effective enough, which is confirmed by the existing problems in the rational use of agroindustrial lands. In our opinion, in order to solve the existing problems, it is necessary to continue the development and development of a mechanism for the rational use of agricultural land.

Today, there is a tendency for owners of land plots to lease them due to the unstable economic situation of agricultural enterprises and organizations, which entails a decrease in the provision of such lands in the authorized capital of agricultural enterprises and organizations. In connection with the above, it can be concluded that the lease of land plots occupies a dominant position. This fact suggests that the transition to a higher level of development of land legal relations in this industry requires significant investments, units of modern equipment, technologies, innovative plant protection products, etc. Integrated formations in the agro-industrial complex, such as a holding, an agrofirm, a financial and agro-industrial group, continue their development process [3].

As you know, the republics that were part of the USSR adhered to the policy of market relations and the elimination of the monopoly for land and private property. However, at that time there was another problem associated with the reform of state and collective agricultural enterprises due to the fact that this type of agricultural production did not have an advantage in the rational and efficient use of land.

Here is an example: in terms of a quantitative indicator, the land plot remained low, and in terms of a qualitative indicator, the level of fertility, which was caused by the process of land degradation, decreased.

Land privatization is the model of land legal relations that was used in most of the countries of the Soviet Union. The greatest success in this model was achieved by the individual private sector of agriculture of the Republic of Kazakhstan and the Republic of Uzbekistan, since this direction of agricultural policy is based on traditions and mentality.

Analysis of foreign experience and the study of the opinions of scientists on the agrarian economy gave us the opportunity to determine the main directions for increasing the efficiency of land relations [4].

These include:

- improvement of state regulation of land relations, including environmental protection measures;

- improving the material and technical support of agriculture;

- improvement of the economic mechanism for increasing the efficiency of the use of land resources. Since the land is not only the main condition of labor, but also the necessary material base of any production process, it, as a means, must be used highly efficiently, which becomes the most important task for agricultural producers [5].

Today we can observe the following picture of the structure of ownership of agricultural land: 
Table 1. The structure of ownership of agricultural land in Russia.

\begin{tabular}{|c|c|c|c|c|c|}
\hline \multirow{2}{*}{ Type of ownership } & \multicolumn{2}{|c|}{$\begin{array}{c}\text { For a period of } \\
\mathbf{0 1 . 0 1 . 2 0 1 0}\end{array}$} & \multicolumn{2}{c|}{$\begin{array}{c}\text { For a period of } \\
\mathbf{0 1 . 0 1 . 2 0 2 0}\end{array}$} & $\begin{array}{c}\text { Comparative } \\
\text { aspect of 2020 in } \\
\text { relation to 2010 }\end{array}$ \\
\cline { 2 - 5 } & Million ha & $\%$ & Million ha & $\%$ & $90 \%$ \\
\hline $\begin{array}{c}\text { Owned by citizens - } \\
\text { physical. persons }\end{array}$ & 120.7 & 30.1 & 108.5 & 28.3 & 5.0 \\
\hline $\begin{array}{c}\text { Owned by a legal entity. } \\
\text { persons }\end{array}$ & 5.0 & 1.2 & 19.2 & Increased 3.8 times \\
\hline $\begin{array}{c}\text { Federal and municipal } \\
\text { property }\end{array}$ & 275.8 & 68.7 & 255.5 & 66.7 & $95.4 \%$ \\
\hline Total & 401.5 & 100 & 383.2 & 100 & - \\
\hline
\end{tabular}

Taking into account the state of land resources of the Russian Federation, there is an objective need to use the achievements of scientists and practitioners in the rational use and protection of lands. These issues have acquired particular urgency at the present stage, during the period of radical reform of social relations, and the formation of an effective system of regulation of land relations and management of the land fund acquires special significance in these conditions.

\section{Actual problems of land legal relations in the agro-industrial complex}

In Russia today, private ownership of the total land use is $80 \%$. The problem of this fact is the passive attitude of the state to stimulating the solution of the problems of land transformations.

Land is a multipurpose resource that is limited to the region and is used at various economic levels. As of today, the total number of agricultural land in Russia is $10 \%$.

One of the most acute problems in Russia is the low percentage of the gross domestic product in agriculture, which is only $1 \%$. But besides this, there is another problem - the unsuitability of land due to the climate and temperature for growing crops.

The situation in agriculture in Russia today is at a low level and cannot even come close to the times of reforms, which is confirmed by products imported from other countries on store shelves [6].

Here we can conclude that in Russia there is a tendency towards a decrease in the cultivation of rural products and the abandonment of many plots that previously served for the cultivation of agricultural products. According to statistics, the number of abandoned agricultural plots is $25 \%$.

At present, many people involved in the cultivation of agricultural crops have no land registration, that is, they are not legally assigned to them, and thus they leave from paying the land tax. The main reasons for the reduction in land use on the territory of Russia include socio-economic, natural, and organizational and economic factors. Also, the reason may be that agriculture is not given sufficient attention and funding, so land users are forced to abandon agricultural land. Land reform, which is one of the reasons for land relations, was carried out during the collapse of the USSR in 1991. Due to the difficult situation, it was carried out quickly and ended in 2000 [7].

At the moment, land legislation is based on outdated laws, despite the fact that they have long been unsuitable for solving the problems of the present time.

Land policy in each state should clearly establish the goals and main tasks of regulating land relations, during which it is possible to change and give impetus to an increase in the area for agricultural use [8] [9].

In our opinion, it is necessary to set the following goals: 
1. To complete the development and formation of a system of land tenure and land use, allowing citizens who are engaged in agriculture to preserve their land. Here, it is necessary to ensure the protection of the rights of every citizen in the issue of land use, that is, to regulate the acquisition and use of land for growing crops.

2. To form a land market that meets all the requirements and its infrastructure.

3. Create conditions and incentives, possibly incentives, for people to use their land competently and efficiently, and for products to meet the requirements of each buyer [10].

Ensure the protection of land holdings so that the land that the state issues is used for its intended purpose and does not stand idle. It is also necessary to create a state body that could be engaged in the protection and monitoring of the proper use of land.

\section{Proposals for improving the land legislation governing land legal relations in the agricultural sector}

Based on the study of the problems of land legal relations in the agro-industrial complex, we have developed a number of proposals that, in our opinion, will allow these problems to be eliminated.

As noted, the lack of demand for land shares is a factor that hinders the effective turnover of agricultural land. This type of land includes land, the owners of which violated the procedural terms and did not receive documents certifying their right to these lands, or received documents, but did not lease shares or did not dispose of these lands in another way [11] [12].

The problem we are considering is very relevant for most regions of the Russian Federation, since according to statistical data, unclaimed land makes up from 20 to 50 percent of the total area of agricultural land. We believe that the solution to this problem is possible if a mechanism is developed to involve these lands in the market turnover [13].

To solve these problems, we offer:

1. Clarify the concept of a land share in the Federal Law of July 24, 2002 No. 101-FZ "On the turnover of agricultural land". We also propose in the same Federal Law to expand the list of cases when land plots from agricultural land, which are in state or municipal ownership, can be provided without bidding [14].

2. For the rational use of agricultural land, we offer the following activities:

- to organize an agrarian and environmental assessment of agricultural land that has been removed from circulation;

- restore a decent level of ecology in unproductive, polluted and reclaimed territories;

- taking into account the influence of market trends, to assess the real value of agricultural land plots;

- put all land plots on the cadastral register;

- to reduce the concentration of fertile lands of large agricultural holdings [15].

These proposals will lead to the efficiency of the procedure for the recognition of municipal property rights to unclaimed land shares for the provision of such shares in the future to effective land users.

\section{Conclusions}

Thus, after analyzing the problems of land legal relations in the agro-industrial complex, we can draw a number of conclusions:

1. Today, there is a tendency for the owners of land plots to lease them due to the unstable economic situation of agricultural enterprises and organizations, which entails a 
decrease in the provision of such lands in the authorized capital of agricultural enterprises and organizations. In connection with the above, it can be concluded that the lease of land plots occupies a dominant position. This fact suggests that the transition to a higher level of development of land legal relations in this industry requires significant investments, units of modern equipment, technologies, innovative plant protection products, etc. Integrated formations in the agro-industrial complex, such as a holding, an agrofirm, a financial and agro-industrial group, continue their development process.

2. At present, many people involved in the cultivation of agricultural crops do not have their land registered, that is, they are not legally assigned to them, and thus they leave from paying the land tax. The main reasons for the reduction in land use on the territory of Russia include socio-economic, natural, and organizational and economic factors. Also, the reason may be that agriculture is not given sufficient attention and funding, so land users are forced to abandon agricultural land.

3. Land policy in each state should clearly establish the goals and main tasks of regulating land relations, during which it is possible to change and give impetus to an increase in the area for agricultural use.

In our opinion, it is necessary to set the following goals:

- to complete the development and formation of a system of land tenure and land use, allowing citizens who are engaged in agriculture to preserve their land. Here, it is necessary to ensure the protection of the rights of every citizen in the issue of land use, that is, to regulate the acquisition and use of land plots for growing agricultural crops;

- to form a land market that meets all the requirements and its infrastructure;

- to create conditions and incentives, possibly incentives for people to competently and effectively use land, and for products to meet the requirements of each buyer;

- to ensure the protection of land ownership so that the land that is issued by the state is used for its intended purpose and does not stand idle. You also need to create a state body that could be engaged in the protection and monitoring of the correct use of land.

4. We propose to clarify the concept of a land share in the Federal Law of July 24, 2002 No. 101-FZ "On the turnover of agricultural land". We also propose in the same Federal Law to expand the list of cases when land plots from agricultural land, which are in state or municipal ownership, can be provided without bidding.

\section{References}

1. T. Tahmasebia, E. Karamia, M. Keshavarzb, Journal of Arid Environments, 180, 1-14 (2020)

2. M. Xiaa, Y. Zhangb, Z. Zhanga, et al., Land Use Policy, 90, 1-10 (2020)

3. J.A. Aznar-Sáncheza, M.Piquer-Rodríguezb, J.F. Velasco-Muñoza, F. ManzanoAgugliaro, Land Use Policy, 87, 1-15 (2019)

4. O. Yildiz, Land Use Policy, 82, 538-549 (2019)

5. P. Le Billon, M. Sommerville, Geoforum, 82, 213-224 (2017)

6. E. Balashov, I. Vladimirov, R. Gizzatullin, et al., Journal of the Saudi Society of Agricultural Sciences, 8, 1-7 (2020) doi.org/10.1016/j.jssas.2020.12.002

7. Y.Griewald, Ecological Economics, 151, 1-9 (2018) doi.org/10.1016/j.ecolecon.2018.04.026

8. P. Le Billon, M. Sommerville, Geoforum, 82, 212-224 (2017) doi.org/10.1016/j.geoforum.2016.08.011

9. R.Marks-Bielska, Land Use Policy, 102, 1-9 (2021) doi.org/10.1016/j.landusepol.2020.105251 
10. D. B. Paz, K. Hendersona, M. Loreau, Ecological Modelling, 437, 1-13 (2020) doi.org/10.1016/j.ecolmodel.2020.109312

11. J.M. Torres-Rojoa, C.A. Francisco-Cruzc, J.F. Islas-Aguirrec, et al., Land Use Policy, 92, 1-10 (2020) doi.org/10.1016/j.landusepol.2019.104438

12. R. Abmana, C. Carney, Food Policy, 94, 1-19 (2020) doi.org/10.1016/j.foodpol.2020.101841

13. P. Koguashvili, B. Ramishvili, Annals of Agrarian Science, 16, 324-326 (2018) doi.org/10.1016/j.aasci.2018.06.007

14. E.B. Barbier, Land Use Policy, 93, 1-11 (2020) doi.org/10.1016/j.landusepol.2019.01.011

15. H. Xiea, H. Lu, Land Use Policy, 68, 356-365 (2016) doi.org/10.1016/j.landusepol.2017.07.053 